кандидат педагогічних наук, доцент

(Житомирський державний університет імені Івана Франка)

\title{
ЗАПОБІГАННЯ ПОМИЛКАМ В УЧНІВСЬКИХ РОБОТАХ НА УРОКАХ УКРАЇНСЬКОЇ МОВИ В 3-4 КЛАСАХ
}

У статті розглянуто актуальні проблеми роботи над попередженням помилок в письмових роботах учнів початкових класів на уроках української мови. 3 метою надання методичної допомоги студентампрактикантам та молодим вчителям початкової ланки здійснено теоретичний аналіз досліджуваної проблеми і подано ї̈ теоретичні засади; запропоновано відповідні методичні рекомендацї̈, зроблено висновки та окреслено перспективи подальших досліджень в означеній галузі.

Ключові слова: вимоги правильності мовлення, мовна культура, формування навичок правопису, типи помилок, вправи, методи і прийоми роботи на уроці.

Постановка проблеми. Одним із показників культури людини, рівня їі інтелекту є мовлення, яке відповідає вимогам правильності - відповідності мовним нормам. Серед найактуальніших завдань сучасної школи, зокрема й початкової, - формування мовної культури учнів. Ще І. Огієнко писав: "Мова - це душа кожної національності, іiі святощі, ії найцінніший скарб... I поки живе мова - житиме й народ, як національність... Не стане мови, не стане національності" [1:11]. Тому важливість предмету "українська мова" в початкових класах, де звучить рідне слово, важко переоцінити, а проблема виявлення, диференціації та виправлення мовних помилок, а також пошук шляхів запобігання їм - серед найактуальніших в сучасній початковій освіті.

Аналіз останніх досліджень та публікацій. Проблеми формування навичок правопису та попередження помилок в мовленні учнів стали об'єктом численних досліджень провідних зарубіжних та вітчизняних психологів (Д. Богоявленський, Л. Божович, С. Жуйков, П. Гальперін), педагогів і методистів (О. Бєляєв, М. Вашуленко, С. Дорошенко, С. Жила, О. Мельничайко, Т. Ладиженська, К. Климова, Д. Кравчук, В. Мельничайко, К. Пономарьова, Т. Потоцька, Т. Рамзаєва, Н. Светловська, М. Соловейчик, О. Хорошковська, С. Цейтлін, В. Цимбалюк, Г. Шелехова та ін.). Вчені наголошують, що саме в період початкового навчання діти найінтенсивніше опановують норми усного й письмового літературного мовлення, вчаться використовувати мовні засоби в різних умовах спілкування відповідно до цілей і змісту мовлення.

Аналіз наукової літератури 3 досліджуваної проблеми дав підстави зробити висновок, що попередження та виправлення помилок невіддільні від усієї системи роботи вчителя 3 навчання мови. Така система розробляється на основі диференціації конкретних типів помилок та вивчення причин виникнення кожного 3 них. Робота $з$ попередження помилок містить такі елементи: 1) виправлення помилок у зошитах учнів; 2) постійна робота на уроці над помилками в усному та писемному мовленні учнів; 3) індивідуальна позаурочна робота над окремими помилками; 4) система вправ, у яких враховуються найімовірніші помилки, аналіз текстів на уроках читання та рідної мови; 5) мовні вправи перед написанням твору, переказу з метою підготовки до правильного використання мовних засобів (слів, сталих виразів, речень); 6) навчання прийомам самоперевірки та редагування написаного тексту [2: 399].

Досвідчені вчителі-практики налаштовують дітей на осмислення мовних норм, вчать їх стежити за правильністю, точністю, різноманітністю, виразністю мовних засобів. Водночас спостереження за навчальним процесом у початкових класах показали, що попередження помилок, особливо студентамипрактикантами, проводиться не завжди систематично, фрагментарно, адже молодий вчитель не завжди уміє визначити тип учнівської помилки і дібрати прийоми для ії запобігання або усунення. Крім того, відсутність єдиної класифікації помилок в методичній літературі ускладнює роботу вчителя в означеному напрямі.

Усе сказане обумовлює актуальність теми статті та визначає її мету - для методичної допомоги студентам-практикантам теоретично обгрунтувати та описати систему роботи, що забезпечує ефективність запобігання помилкам у письмових роботах учнів початкових класів. Досягнення поставленої мети передбачає розв'язання таких завдань: здійснити теоретичний аналіз досліджуваної проблеми, узагальнити теоретичні засади роботи з попередження помилок в роботах учнів $3-4$ класів; запропонувати науково обгрунтовані рекомендації для такої роботи.

У процесі досягнення поставлених мети й завдань використовувалися методи дослідження: теоретичні - аналіз і синтез психолого-педагогічних, мовознавчих і методичних праць із досліджуваної проблеми; метод теоретичного прогнозування для визначення об'єкта, предмета, мети, гіпотези та 
завдань дослідження; узагальнення педагогічного досвіду превентивної роботи над помилками. Емпіричні: спостереження за навчальним процесом, бесіди з учителями-практиками, зі студентами ННI педагогіки; аналіз відвіданих занять, усних відповідей і письмових робіт учнів та студентів, педагогічний експеримент, статистична обробка результатів перевірки.

Виклад основного матеріалу. Психолого-фізіологічною основою дослідження проблеми попередження помилок $є$ вчення про закономірності вищої нервової діяльності І. Павлова: "Все навчання полягає в утворенні тимчасових зв'язків, а це і $\epsilon$ думка, міркування, знання" [3: 509]. Вивчаючи особливості засвоєння понять у дитячому віці, Л. Виготський довів, що попередня розумова діяльність, яка формує узагальнення, "не анулюється і не зникає..., а є необхідною передумовою нової роботи думки" [4: 26]. Таке явище називається в психології аперцепцією. Важливість цього явища доводить більшу стійкість раніше здобутих знань, сформованих умінь і навичок порівняно 3 тими, які з'являються пізніше. Іншими словами, помилку легше попередити, ніж потім іiї виправляти. Такий висновок підтверджує положення, що необхідність роботи з запобігання помилкам випливає із природи мислення, обумовлена законами психології і фізіології.

Молоді вчителі традиційно звертають увагу на орфографічні та пунктуаційні помилки, у той час як для підвищення рівня мовленнєвої культури учнівських робіт варто звертати й на інші їх види.

Наведемо приклади лексичних помилок: повторення слів, що зумовлене бідністю словникового запасу; неточне вживання слова внаслідок неправильного розуміння його значення (На горі сидів зайчик (замість на горбочку); порушення правильної сполучуваності слів (Потяг робив швидкість (замість набирав швидкість); уживання слів без урахування їх емоційно-експресивного та оцінного забарвлення (ворони щеебетали (замість каркали); вживання діалектних слів і словосполучень (хлобись в калабаню (замість впав у калюжу) [5: 327-328].

Добираючи опорні слова для складання речень чи тексту, вчителю необхідно потурбуватися, щоб ці слова були зрозумілими дітям. В іншому випадку школярі можуть вжити їх неправильно [6: 22-25]. Так, діти припустились помилок, складаючи речення за опорними словами на тему "Бібліотека": На абонентах стоять різні книги. У бібліотеці є словники, підручники, каталоги. Я люблю читати фантастику, книжки, казки, оповідання.

Серед граматичних назвемо такі: порушення керування (дякую вас, у відміну від тебе); порушення узгодження між підметом і присудком (Мені сподобалось ялинка), між іменником та прикметником (веселе день народження) та ін.

Констатувальний зріз дав змогу проаналізувати помилки в письмових роботах учнів 3-4-х класів та виявити ще й такі: порушення логічної послідовності у викладі подій, стилістичної правильності мовлення, зокрема, вживання розмовних слів; пропуск букв у словах. Також в усному і писемному мовленні молодших школярів зустрічається багато помилок, які в методиці навчання української мови називають мовними.

Найповніше визначення мовних помилок і недоліків знаходимо у працях Т. А. Ладиженської: "весь негативний мовний матеріал ділиться на помилки i недоліки. Помилка - це порушення вимог правильності мови, порушення норм літературної мови... Недолік - це порушення вимог правильності мови, порушення рекомендацій, пов'язаних із поняттям гарної мови, тобто багатої, точної i виразної" [7: 30].

Однією з причин орфографічних помилок у письмових роботах учнів $є$ розрив між теоретичними знаннями та вміннями й навичками. В молодших школярів недостатні орфографічна пильність, навички самоконтролю, та діти зазвичай пишуть, як чують. Серед орфографічних помилок спостерігаються, зокрема, фонетико-графічні (пропуск букв, заміна одних літер іншими, подібними за звучанням i накресленням, перестановка, графічне спотворення слів) та власне орфографічні (помилки у вживанні буквосполучень $b o$, йо, апострофа, м'якого знака, подвоєнь приголосних, спрощень в групах приголосних тощо).

Для того щоб окреслити загальну картину наявних помилок у письмових роботах учнів початкових класів, ми провели дослідження серед учнів початкових класів під час педагогічної практики студентів НHІ педагогіки Житомирського державного університету ім. І. Франка. Мета дослідження полягала в тому, щоб визначити рівень розвитку мовлення учнів 3-4-х класів. У цьому полягав перший етап - збір необхідної інформації про учнів експериментальних та контрольних груп. Для цього на уроках української мови в 3-4 класах було проведено констатувальний зріз.

Аналіз робіт учнів початкових класів дав можливість розглянути найпоширеніші кожного 3 названих типів помилок. 1) Пропуск літер (лсток- листок, зиит- зошит, дері- двері, вчір-вечір, пхнуть-пахнуть, сльні-сильні, нги-ноги, облччя-обличчя). Пропуск букв, що позначають голосні звуки, зокрема, пояснюється тим, що в період навчання грамоти діти недостатньо засвоїли знання про складотворчу роль голосного у слові, тому, зосереджуючись на приголосному, пропускають голосний. Пропуск приголосного можна пояснити близькістю розташування звуків у слові в артикуляційному плані. Говорячи про методичні причини наявності таких орфографічних помилок, назвемо найістотнішу - 
недостатня увага вчителя до фонемного аналізу чи неправильний підхід до навчання складоподілу, ролі голосного в ньому. 2) Заміна літер, зокрема, $\boldsymbol{\epsilon}, \boldsymbol{ю ,} \boldsymbol{g}, \boldsymbol{i}$, що позначають м'якість попереднього приголосного (земла-земля, свато-свято, лутий-лютий, трете-третє). Причина їх появи: учні не відчувають зв'язку між м'якістю попереднього приголосного звука і вимовленим голосним. Утворенню зв'язку між приголосним і голосним найчастіше заважає ізольоване промовляння м'якого приголосного. 3) Нечисленні, але наявні і суто графічні помилки, тобто ті, що пов'язані зі схожістю графічних елементів

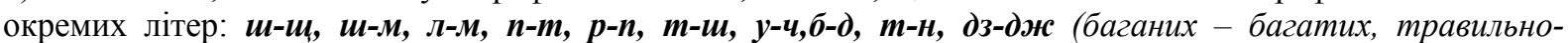
правильно, дібусь-дідусь, уому-чому, дзерело-лжерело). Ймовірно, причина - прогалина у навчанні письма цих літер: відсутність зіставлення і протиставлення графічної будови літер, поелементного їх аналізу. 4). Значну частину складають помилки, на позначення м'якості приголосних у середині та кінці слова (силні - сильні, маленкі - маленькі, ден - день). Особливо часто помиляються у позначенні сполучень ьо, йщ.. Серед помилкових написань зустрічаємо неправильне поєднання літер в, й $з$ o (ному ньому, согодні - сьогодні, льн- льон, малований - мальований). Такі помилки можна пояснити тим, що недостатньо проводилась робота над звукобуквеним аналізом слів, зіставленням складів із твердими та м'якими приголосними. Серед причин - й незміцнілість дрібних м'язів руки. Списуючи чи пишучи під диктовку, діти промовляють слова зі швидкістю, яка перевищує їх темп письма, тому пропускається одна з двох літер, які позначають один звук.

Перевіряючи учнівські перекази і твори, учитель аналізує, чи оволодів учень інформативнозмістовими та структурно-композиційними вміннями, зокрема: усвідомлювати тему і основну думку висловлювання; розмежовувати основне і другорядне, пов'язувати між собою думки в окремі частини (мікротеми). Тому до змістових помилок слід віднести такі: інформаційно-тематичні (невідповідність твору вибраній темі або змісту переказу первинному тексту; наявність інформації, не пов'язаної 3 основною думкою тексту; виклад фактів, які не відповідають дійсності тощо); помилки, що порушують структуру тексту (непропорційність частин тексту - вступу, основної частини, висновку - або відсутність якоїсь із них, непослідовність викладу).

Отже, помилки в письмових роботах учнів можна поділити на такі: орфографічні; пунктуаційні (неправильне вживання розділових знаків); граматичні (виникають як результат порушення граматичних норм); лексичні; стилістичні (вживання слова, яке не відповідає стилю висловлювання); змістові; синтаксичні (неправильна побудова речення).

Під час констатувального експерименту проведено діагностику рівня розвитку правильного зв'язного мовлення учнів експериментальної та контрольної груп, здійснено аналіз одержаних результатів. Зроблено висновок, що учні обох груп пам'ятають текст, але не завжди уміють логічно, послідовно і без помилок передати його зміст, їм важко висловлювати власне ставлення до героїв та подій, описаних у тексті. Іноді зустрічається поверхове, примітивного сприймання змісту твору.

Далі був проведений формувальний етап педагогічного есперименту, мета якого - перевірити на практиці можливість і ефективність використання спеціальних вправ із запобігання мовним помилкам учнів початкових класів на уроках української мови в 3-4 класах. Для експериментального навчання було запропоновано спеціальну систему роботи. Методологічною основою розробки програми формувального експерименту стали досягнення мовознавства, педагогіки, психології та лінгвометодики. Вона грунтується на дидактичних принципах науковості, систематичності та послідовності, активності, доступності, опори на цілісне, безпосереднє емоційне сприймання текстів; сприяння розвиткові творчих здібностей, самостійності учнів тощо.

Означена методика містила такі компоненти: 1) спеціально дібрані тексти, що можуть бути використані для виконання вправ, спрямованих на запобігання помилкам в мовленні учнів; це доступний, цікавий для дітей мовний матеріал, який відповідає конкретній темі, меті і завданням уроку, допомагає систематизувати весь комплекс завдань, спрямованих на попередження помилок; 2) методи і відповідні прийоми роботи на уроці, спрямовані на запобігання помилкам, зокрема методи: розповідь вчителя (прийоми використання опису, переказу, пояснення правильного написання, наочності, друкованих джерел, технічних засобів навчання, пояснення незрозумілих слів, узагальнення етичного характеру, формулювання теми, ідеї тексту та ін.), метод бесіди репродуктивного і евристичного характеру (прийоми постановки запитань і завдань пізнавального та проблемного характеру, обговорення i коригування відповідей учнів, опрацювання незрозумілих слів, аналіз тексту, формулювання висновків 3 бесіди та ін.), метод вправ, у тому числі робота в парах і групах (диктанти, списування різних типів, у тому числі творчого характеру, завдання на відтворення змісту тексту та ін.), метод самостійної роботи (прийоми: переказ тексту, написання творів за пропонованою темою, самостійні висновки тощо).

У контрольних групах навчання проводилось традиційно, а в експериментальних - за новою методикою. Заняття в групах $з$ приблизно однаковим рівнем успішності відповідали чинним програмам. На підсумковому етапі експерименту аналізувались результати дослідного навчання на основі письмових робіт учнів - переказу з власною кінцівкою. Проведено аналіз даних: в учнів експериментальних груп показник високого рівня сформованості умінь правильно висловлюватись становив 19 \% на противагу 7 \% у 
контрольних; показник середнього рівня в експериментальних - $74 \%$, контрольних - 63 \%; низького рівня в експериментальних - 7 \%, у контрольних $-30 \%$.

Висновки 3 даного дослідження i перспективи подальших розвідок у даному напрямку. Проведене дослідження допомогло зробити такі висновки: ефективність запобігання помилкам в письмових роботах учнів початкових класів підвищиться, якщо робота грунтуватиметься на досягненнях лінгвістичної науки, а також специфічних для уроків мови здобутках психолого-педагогічної i методичної наук; відпрацювання відповідних текстотворчих умінь учнів початкових класів здійснюватиметься на основі доцільної продуманої системи використання різноманітних форм, методів і прийомів навчання, підпорядкованих сучасним вимогам. Учні експериментальних груп, де велася робота за пропонованою методикою, продемонстрували вищий рівень сформованості зазначених умінь. Це свідчить про ефективність розробленої методики, психолого-педагогічного забезпечення і організації формувального експерименту.

Результати проведеного педагогічного експерименту виявили перспективи для подальшого наукового пошуку, адже проведене дослідження не вичерпує всіх аспектів проблеми. Потребують окремого з'ясування розробка цілісної програми взаємопов'язаного вивчення всіх розділів науки про мову, розгляд проблеми усунення та запобігання помилкам під час вивчення розділів мовознавства, розробка відповідної системи вправ в позакласній роботі тощо.

\section{СПИСОК ВИКОРИСТАНИХ ДЖЕРЕЛ ТА ЛІТЕРАТУРИ}

1. Огієнко І. Наука про рідномовні обов'язки / І. Огієнко - Львів : Фенікс, 1995. - 47 с.

2. Львов М. Р. Методика обучения русскому языку в начальных класах : [учеб.пособие для студ.] / М. Р. Львов - 2-е изд., перераб. - М. : Просвещение, 1987. - 415 с.,

3. Павлов И. П. Избранные труды / И. П. Павлов - М. : Издательство АПН СССР, 1951. - 614 с.

4. Выготский Л. С. Избранные психологические исследования / Л. С. Выготский. - М. : АПН РСФСР, 1956. 519 c.

5. Методика навчання української мови в початковій школі : [навчально-методичний посібник для студентів вищих навчальних закладів] / За наук. ред. М. С. Вашуленка. - К. : Літера ЛТД, 2010. - 364 с.

6. Гордієнко О. А. Словникова робота на уроках української мови в початковій школі / О. А. Гордієнко, Т. О. Шевчук // Педагогічна Житомирщина, 2008. - № 1. - С. 22-25.

7. Методика развития речи на уроках русского языка: Кн. для учителя / Н. Е. Богуславськая, В. И. Капинос, А. Ю. Купалова и др. / За ред. Т. А. Ладиженской - М. : Просвещение, 1991. - С. 30-31.

\section{REFERENCES (TRANSLATED \& TRANSLITERATED)}

1. Ohiienko I. Nauka pro ridnomovni oboviazky [Science Dealing with Mother Tongue Duties] / I. Ohiienko. - Lviv : Feniks, 1995. $-47 \mathrm{~s}$.

2. Lvov M. R. Metodyka obucheniia russkomu yazyku v nachalnykh klassakh [Methodology of Teaching Russian in Primary School] : [ucheb. posobiie dlia stud.] / M. R. Lvov - 2-e izd., pererab.- M. : Prosveshcheniie, 1987. - $415 \mathrm{~s}$.

3. Pavlov I. P. Izbrannyie trudy [Selected Works] / I. P. Pavlov - M.: Yzdatelstvo APN SSSR, 1951. - 614 s.

4. Vyhotskyi L. S. Izbrannyie psykholohycheskye issledovaniia [Selected Psychological Researches] / L. S. Vyhotskyi - M. : APN RSFSR, 1956. - 519 s.

5. Metodyka navchannia ukrains'koi movy $\mathrm{v}$ pochatkovii shkoli [Methodology of Teaching Ukrainian in Primary School] : [navchal'no-metodychnyi posibnyk dlia studentiv vyshchykh navchalnykh zakladiv] / Za nauk. red. M. S. Vashulenka. - K. : Litera LTD, 2010. - $364 \mathrm{~s}$.

6. Hordiienko O. A. Slovnykova robota na urokakh ukrains'koi movy v pochatkovii shkoli [Dictionary Work at Ukrainian Language Lessons in Primary School] / O. A. Hordiienko., T. O. Shevchuk // Pedahohichna Zhytomyrshchyna, 2008. № 1. - S. 22-25.

7. Metodyka razvitiia rechi na urokakh russkoho yazyka [Methodology of Speech Development at Russian Language Lessons] : [kn. dlia uchytelia] / N. E. Bohuslavskaia, V. Y. Kapynos, A. Yu. Kupalova y dr. / Za red. T. A. Ladyzhenskoi - M. : Prosveshcheniie, 1991 - S. 30-31.

\section{Гордиенко Е. А. Предотврацение очибок в ученических работах на уроках украинского языка в 3-4 классах.}

В статье рассматриваются актуальные проблемы работы по предупреждению ошибок в письменных работах учеников начальных классов на уроках украинского языка. С иелью подачи методической помощи студентам-практикантам и молодым учителям начального звена произведен теоретический анализ исследуемой проблемы и даются методические рекомендации, сделаны выводы и очерчены перспективы дальнейших исследований в данной области.

Ключевые слова: требования правильности речи, языковая культура, формирование навыков правописания, типь ошибок, упражнения, методы и приёмы работы на уроке. 


\section{Hordiienko O. A. Prevention of Errors in Pupils' Works on the Ukrainian Language Lessons (Grades 3-4).}

The article goes on to say that the importance of the subject "Ukrainian language" is difficult to over-estimate, and a problem of errors in speech and searching for the ways of their prevention are among the most actual in modern primary education. The analysis of scientific literature on the investigated issue allowed us to draw the conclusion, that prevention and correction of errors must have systematic character. The necessity of prevention of errors comes out the nature of the thinking process of a child, conditioned by the laws of psychology and

physiology. The aim of the article is to ground and describe the system of work that provides efficiency of prevention of errors in written works of pupils in primary school (for methodological help for students during their school practice). In the process of achievement of the aim such methods of research were used: theoretical (an analysis and synthesis of psychological, pedagogical, linguistic and methodological works in the investigated problem; method of theoretical prognostication; generalization of pedagogical experience of preventive prosecution of errors); empiric (watching the educational process, conversations with teachers and pupils; analysis of the visited lessons, verbal answers and written works of pupils and students, pedagogical

experiment, statistical analysis of the results of the experiment). The establishing stage of the experiment revealed that errors in written works of pupils can be divided into the following types: orthographic; punctuation; grammatical; lexical; stylistic content; syntactic. The special system of work is offered in the process of the forming stage of the pedagogical experiment. It is the methodology aimed at prevention of errors

in coherent speech of pupils. The methodology contains such components: specially selected texts and corresponding to them methods of work in a lesson. In control groups lessons were conducted traditionally, and in the experimental one the lessons were conducted in an experimental way. The control section was performed in experimental and control groups; the results of the experiment were analyzed and conclusions were made. The research helped to make the following conclusions: efficiency of prevention of errors will rise in written works of pupils of primary school if the system of work will be carefully planned and will take into account the age and individual features of pupils. The prevention of pupils' errors improves understanding by them various texts, assists in forming abilities to create texts, as well as skills to edit and analyse their own and other's texts at the elementary level.

Key words: requirements of rightness of speech, language culture, forming of skills of spelling, types of errors, exercise, methods of work in a lesson. 